\title{
A comparative study of artificial bone graft versus allograft in the reconstruction of defects after benign tumor curettage
}

\section{Benign kemik tümörlerinin küretajı sonrası oluşan defektlerin rekonstrüksiyonunda kullanılan sentetik kemik greftleri ve allogreftlerin karşılaştırılması}

\author{
Fener Çelebi ${ }^{1}$, Ahmet Fevzi Kekeç², Recep Öztürk ${ }^{3}$ \\ ${ }^{1}$ Memorial Diyarbakır Hastanesi, Ortopedi ve Travmatoloji, Diyarbakır \\ ${ }^{2}$ Dörtyol Devlet Hastanesi, Ortopedi ve Travmatoloji, Hatay \\ ${ }^{3}$ Polatlı Devlet Hastanesi, Ortopedi ve Travmatoloji, Ankara
}

Dergiye Ulaşma Tarihi:21.11.2017 Dergiye Kabul Tarihi:06.12.2017 Doi: 10.5505/aot.2018.26056

\section{ÖZET}

GİRIŞ ve AMAÇ: Kemik vücudun iskeletini oluşturan, son derece karışık ve yüksek oranda özelleşmiş bir bağ dokusudur. Ancak bazen travma, enfeksiyon ve tümörler gibi nedenlerden ötürü oluşan kemik defektleri, kemik dokusu ile iyileşemeyebilir. Böyle durumlarda iyileşmeyi kolaylaştırmak veya başlatmak için kemik defektlerinin kemik greft materyalleri ile doldurulması gerekebilir. Biz bu çalışmada benign kemik tümörlerinde defekti doldurmak için sentetik kemik grefti kullanılan hastalar ile kansellöz allogreft kullanılan hastaların greftlerinin kaynama hızlarını değerlendirmeyi amaçladık.

YÖNTEM ve GEREÇLER: Bu çalışmada 2009 - 2013 tarihleri arasında Dr. A.Y. Ankara Onkoloji Eğitim ve Araştırma Hastanesi Ortopedi ve Travmatoloji Kliniği’nde benign kemik tümörü tanısı alan ve cerrahi tedavi yapılan hastalarda kullanılan greftlerden sentetik kemik grefti (beta trikalsiyum fosfat) ile kansellöz allogreft arasındaki kaynama süreleri incelenmiştir. Vakalar retrospektif olarak değerlendirilmiştir ve her iki grup için 26' şar hasta çalışmaya dahil edilmiştir.

BULGULAR: Sentetik greft kullanılan hastalarda kaynama süresi ortalaması 149.26 gün ve kansellöz greft kullanılan hastalarda ise 103.35 gündür. 20 yaş altındaki hastalarda kaynama süresi ortalaması 125.38 gün ve 21 yaş ve üstündeki hastalarda 124.35 gündür. Çalışma sonuçlarına göre sentetik greft kullanılan hastalar ile kansellöz greft kullanılan hastalar arasında kaynama süresi açısından istatistiksel olarak anlamlı fark bulunmaktadır $(\mathrm{U}=160,500 \mathrm{p}<0.05)$.

TARTIŞMA ve SONUÇ: Benign kemik tümörleri genellikle kavitenin küretajı, agresif tümörlerde adjuvan uygulanması ve oluşan defektin doldurulması ile tedavi edilir. Günümüzde defekti doldurmak için Polimetilmetakrilat (PMMA), sentetik kemik grefti, allogreft kemik ve otogreft kemik kullanılmaktadır. Allogreftlerin bulaşıcı hastalık, derin enfeksiyon ve riskleri mevcut olup biyolojik özellikleri hazırlandıktan sonra değişmektedir. Otogreftlerde donör saha morbiditesi mevcut olup miktarları sınırlıdır. Bazı yazarlar defektleri boş bırakmayı önermekte fakat bu da erken kırık ya da kollapsa sebep olabilmektedir. Bu kısıtlılıklardan kaçınmak için sentetik kemik greftlerinin kullanımı giderek popüler hale gelmiştir fakat bu çalışmadan çıkan sonuca göre sentetik allogreft olarak beta trikalsiyum fosfat kansellöz allogrefte göre daha geç kaynamaktadır.

Anahtar Kelimeler: benign kemik tümörleri, allogreft, sentetik kemik grefti

\begin{abstract}
INTRODUCTION: Bone is a complex and specialized connective tisssue. However, bone defects caused by trauma, infection and tumors sometimes may not heal with bone tissue. In such cases, bone defects may need to be filled with bone graft materials to facilitate or start healing. In this study, we aimed to evaluate the bone healing rates of grafted defects with synthetic bone grafts and cancellous allografts in benign bone tumors. METHODS: The union rates between synthetic bone grafts (beta tricalcium phosphate) and cancellous allografts used in patients who were diagnosed benign bone tumor treated surgically in Dr. A. Y. Ankara Oncology Training and Research Hospital Orthopedics and Traumatology Clinic between 2009 and 2013. The cases were evaluated retrospectively and 26 patients were included for both groups.
\end{abstract}


RESULTS: The mean duration of graft union was 149.26 days in patients using synthetic grafts and 103.35 days in patients using cancellous grafts. The mean duration of union was 125.38 days in patients under 20 years of age and 124.35 days in patients 21 years and older. There is a statistically significant difference in the duraton of graft union between the patients with synthetic grafts and those with cancellous allografts $(p<0.05)$. DISCUSSION and CONCLUSION: Benign bone tumors are usually treated with curettage of the cavity, adjuvant application in aggressive tumors, and filling of resulting defect. Today, polymethylmethacrylate, synthetic bone grafts, allografts and autografts are used to fill the defect. Allografts have risk of infectious diseases,deep infection and usually change their biological properties after prepared. In autografts, donor site morbidity exists and sources are limited. Some authors suggest leaving the defects empty, but this can lead to premature fractures or collapse. To avoid these limitations, the use of synthetic bone grafts has become popular, but as a result of this study, beta-tricalcium phosphate as a synthetic allograft has been healed later than cancellous allografts.

Keywords: benign bone tumors, allograft, synthetic bone graft

\section{GİRIŞ}

Kemik vücudun iskeletini oluşturan, son derece karışık ve yüksek oranda özelleşmiş bir bağ dokusudur. Yaşam boyunca, herhangi bir skar dokusu oluşturmadan kendi kendine özel bir rejenerasyon veya remodeling gösterme kapasitesi mevcuttur. Ancak bazen travma, enfeksiyon, kistler ve tümörler gibi nedenlerden ötürü oluşan kemik defektleri, kemik dokusu ile iyileşemeyebilir. Böyle durumlarda iyileşmeyi kolaylaştırmak veya başlatmak için kemik defektlerinin kemik greft materyalleri ile doldurulması gerekebilir.

Benign kemik tümörleri genellikle asemptomatiktir ve insidental olarak tan konur. Semptomatik olduklarında lokalize ağrı, şişlik, deformite ve patolojik kırığa yol açabilir. Çoğunlukla küretaj ve oluşan kavite büyükse patolojik kırık riskini azaltmak için kavitenin kemik greftiyle doldurulmas1 gerekmektedir. (1,2,3). Bu kemik greftleri otolog, allogreft ve doku mühendisliğinin gelişmesi sonucu üretilen sentetik kemik greftlerdir. Otolog kemik greftleri; kemik defektlerinin, spinal füzyon ve kırık tedavisinde kemik iyileşmesini sağlayan en etkili greft materyalidir. Ancak greftin sinırlı miktarda alınabilmesi, ameliyat süresini uzatmas1, istenilen biçim ve boyutlarda hazırlanabilme güçlüğü, alıcı sahada ameliyat yarası kalması ve greftin alındığı yerde ağrı olması olumsuz yönlerini oluşturur. Allogreftlerde bu olumsuz özelliklerin birçoğu olmamakla birlikte kadavraya ihtiyaç duyulması ve hastalık bulaştırma (HIV, Prion) ihtimali devam etmektedir. Son yüzyılda doğal kemik greftlerine alternatif olarak ortaya çıkan sentetik kemik greftleri sentetik olduklarından sınırsız bir greft kaynağı sağlarlar (4). En çok kullanılanlar, hidroksiapatit ve trikalsiyum fosfat gibi kalsiyum içeren bileşenlerdir. $\mathrm{Bu}$ maddelerin kolay sterilizasyon ve ucuzluk gibi avantajları vardır. Yapılan çalışmalarda iliak krest otogreftleri ile karşılaştırıldıklarında daha az ağrı, operasyon süresi, kan kaybı ve komplikasyona sebep oldukları gösterilmiştir (5). Aynı zamanda allogreftle benzer kaynama sürelerine sahip olmaları kullanım alanlarını arttırmıştır.

Biz bu çalışmada benign kemik tümörlerinde defekti doldurmak için sentetik kemik grefti kullanılan hastalar ile kansellöz allogreft kullanılan hastaları kaynama süreleri açısından değerlendirmeyi amaçladık.

\section{YÖNTEM ve GEREÇLER}

Bu çalışmada Şubat 2009 - Nisan 2013 tarihleri arasında Dr. A. Y. Ankara Onkoloji Eğitim ve Araştırma Hastanesi Ortopedi ve Travmatoloji Kliniği'nde benign kemik tümörü tanıs1 alan ve cerrahi tedavi yapılan hastalarda kullanılan greftlerden sentetik kemik grefti (beta TCP, beta trikalsiyum fosfat) ile kansellöz allogreft arasındaki kaynama zamanlarının değerlendirilmesi amaçlanmıştır. Vakalar retrospektif olarak değerlendirilmiştir ve her iki grup için 26' şar hasta çalışmaya dahil edilmiştir. Ortalama takip süresi 2,5 y1ldir.

Dahil olma kriterleri

1) Benign kemik tümörü nedeniyle sentetik veya kansellöz allogreft kullanılan hastalar

2) Her iki cins kız/erkek

Dışlanma kriterleri

1) Malign kemik tümörleri

2) Benign kemik tümörlerinde otogreft kullanılan hastalar olarak belirlenmiş ve hastalar bu 
kriterlere göre çalışmaya dahil edilmiştir.

Tablo 1'de sentetik kemik grefti ve kansellöz allogreftle opere edilen hastaların demografik özellikleri, tümörlerinin lokalizasyonları ve komplikasyon sayıları gösterilmiştir.

Çalışmamıza alınan olgulardan 21'i (\% 40,4) kadın, 31'i (\% 59,6) erkekti. Yaş ortalaması $25,7 \pm 18$ olarak saptanmıştır. 18 olguda (\% 34.6) üst ekstremiteye, 34 olguda (\% 65.4) alt ekstremiteye greft uygulanmıştır. Benign kemik tümörlerinde greft uygulanan en sik lokalizasyon femur proksimali ve humerus proksimali olarak saptanmıştır.

Çalışmaya alınan tüm hastalarda tümör tamamen ekspoze edildikten sonra neokorteks eksize edilmiş ve detaylı küretaj yapılmıştır. Bütün gross tümör çıkartıldıktan sonra tümörün tamamının çıkarıldığından emin olmak ve kaviteyi debride etmek içim yüksek hızlı bör kullanılmıştır. Börün her tekrarlanışında bol salinle irrigasyon yapılmıştır ve adjuvan olarak koterizasyon yapılmıştır.

Hastalar ilk etapta 45 gün aralıklarla, yeni kemikleşmenin görüldüğü zamandan sonra 6 aylık aralıklarla çekilen 2 yönlü direk grafilerle değerlendirilmiştir. Küretaj sonras1 greftleme yapılan defekte konulan greft materyalinin rezorbe olduğu ve greft alanında kemikleşmenin sağlandığı post-operatif radyografiler ayn hekim tarafindan değerlendirilmiştir (Resim 1, Resim 2).

Sentetik veya kansellöz greft kullanılan benign kemik tümörlü olguların histopatolojik tanılarının dağılımı Tablo 2'de gösterilmiştir.

Çalışmamıza dahil edilen 52 benign kemik tümörlü hastanın histopatolojik tanıları değerlendirildiğinde ilk iki sırayı \% 30.8 'le (16/52) basit kemik kisti ve \% 27'yle (14/52) enkondrom almaktadır.

\section{Istatistiksel analiz}

Çalışmada elde edilen verilerin analizi "SPSS 15.0" paket programı ve tablo düzenlemeleri "Ms Office Excel 2010" programı ile yapılmıştır. Verilerin analizinde kullanılacak testlere karar verilmesinde n (gözlem sayısı) dikkate alınmıştır. Gözlem sayısının 30'dan küçük olması sebebi ile analizlerde parametrik olmayan testlerden Mann-Whitney U Testi kullanılmıştır. Bağımsız Gruplar MannWhitney U Testi, bağımsız iki grubun nicel bir değişken açısından karşılaştırılmasında kullanılan test tekniğidir. Çalışmada \%95 güven düzeyi ile çalışılmış ve alfa katsayısı (p) 0.05 olarak kabul edilmiştir.

Tablo 1: Sentetik kemik grefti ve kansellöz allogreftle opere edilen hastaların demografik özellikler ve lokalizasyonların dağılımı

\begin{tabular}{|l|c|c|c|}
\hline & $\begin{array}{c}\text { Sentetik } \\
\text { kemik } \\
\text { grefti } \\
(26)\end{array}$ & $\begin{array}{c}\text { Kansellöz } \\
\text { allogreft } \\
(26)\end{array}$ & Toplam \\
\hline Cinsyet K/E & $17 / 9$ & $9 / 17$ & $26 / 26$ \\
\hline Yaş & $26.1 \pm 19.3$ & $25.3 \pm 19.3$ & $25,7 \pm 18$ \\
\hline Üst ekstremite & 10 & 8 & 18 \\
\hline Alt ekstremite & 16 & 18 & 34 \\
\hline Metafiz & 21 & 22 & 43 \\
\hline Diafiz & 4 & 2 & 6 \\
\hline Epifiz & 1 & 2 & 3 \\
\hline Nüks & $3(\% 11.5)$ & $2(\% 7.7)$ & 5 \\
\hline Komplikasyon & 2 & 0 & 2 \\
\hline
\end{tabular}

Tablo 2: Sentetik veya kansellöz greft kullanılan benign kemik tümörlü olguların histopatolojik analizi

\begin{tabular}{|l|c|c|c|c|}
\hline Tanı & $\begin{array}{c}\text { Sentetik } \\
\text { kemik } \\
\text { grefti } \\
\text { öz } \\
\text { allogref } \\
\text { t }\end{array}$ & $\begin{array}{c}\text { Kansell } \\
\text { Toplam }\end{array}$ & $\%$ \\
\hline $\begin{array}{l}\text { Basit kemik } \\
\text { kisti }\end{array}$ & 6 & 10 & 16 & $\begin{array}{c}30 \\
, 8\end{array}$ \\
\hline Enkondrom & 9 & 5 & 14 & 27 \\
\hline $\begin{array}{l}\text { Fibröz } \\
\text { displazi }\end{array}$ & 3 & 3 & 6 & $\begin{array}{c}11 \\
, 6\end{array}$ \\
\hline $\begin{array}{l}\text { Dev hücreli } \\
\text { tümör }\end{array}$ & 1 & 3 & 4 & 7, \\
\hline $\begin{array}{l}\text { Anevrizmal } \\
\text { kemik kisti }\end{array}$ & 2 & 2 & 4 & 7, \\
\hline $\begin{array}{l}\text { NOF } \\
\text { Fibrohistiosi } \\
\text { tik lezyon }\end{array}$ & 1 & 1 & 2 & $\begin{array}{c}7, \\
8\end{array}$ \\
\hline $\begin{array}{l}\text { Kondroblast } \\
\text { om }\end{array}$ & 1 & 0 & 1 & $\begin{array}{c}1, \\
9\end{array}$ \\
\hline $\begin{array}{l}\text { Eozinofilik } \\
\text { granülom }\end{array}$ & 1 & 0 & 1 & $\begin{array}{c}1, \\
9\end{array}$ \\
\hline $\begin{array}{l}\text { Intraosseoz } \\
\text { lipom }\end{array}$ & 1 & 0 & 1 & $\begin{array}{c}1, \\
9\end{array}$ \\
\hline
\end{tabular}


Resim 1. Beta trikalsiyum fosfat sentetik grefti ve plak kullanılarak iyileşme sağlanmış bir basit kemik kisti defekti



Resim 2. Kansellöz allogreft ve plak kullanılarak iyileşme sağlanmış bir fibrohistiositik lezyon

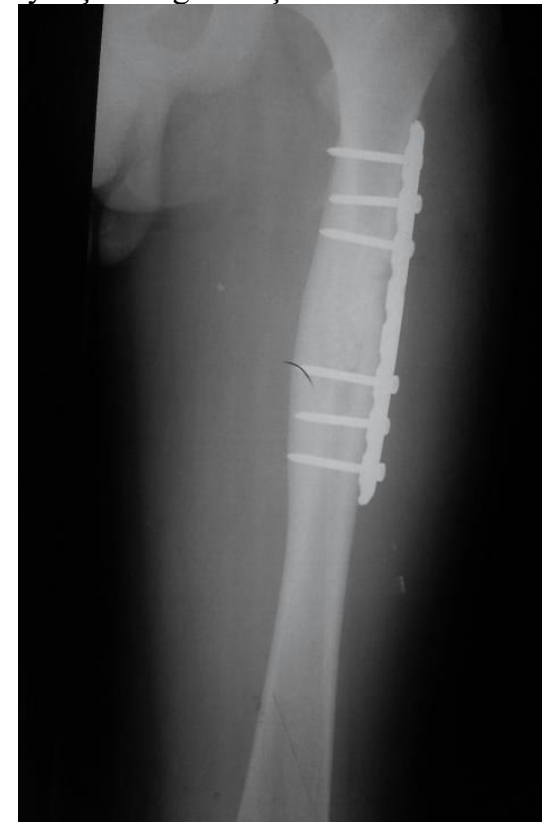

\section{BULGULAR}

Sentetik kemik grefti kullanılan 26 olgudan üçünde kaynama gerçekleşmeden tekrar operasyon yapıldığından hastalar çalışma dışı bırakıldı. İki hastanın birinde 1. ayda diğerinde 2. ayda yüzeyel efeksiyon gelişmesi nedeniyle oral antibiyotik başlandı. Antibiyotiğe cevap alınamayınca yara yeri debridmanı yapılıp sentetik greft çıkarıldı. Ardından defektif alan kansellöz allogreft ile dolduruldu. 3. hastada ise 2. ayın sonunda nüks etmesi üzerine hastaya tekrar küretaj yapılıp, defekt kansellöz allogreftle dolduruldu.

Kansellöz greft kullandığımız 3 hastada tam kemik oluşumu görüldükten sonra nüks görüldü. $\mathrm{Bu}$ hastalar tekrar opere edildiğinde kullanılan kansellöz greftlerin makroskobik olarak yeni kemik oluşturduğu görüldü ve sadece nüks eden kısma küretaj ve kansellöz greftleme yapıldı.

Sentetik greft kullanılan hastalarda kaynama süresi ortalamasi $149.26 \pm 68.95$ gün ve kansellöz greft kullanılan hastalarda ise $103.35 \pm 74.37$ gündür. 20 yaş altındaki hastalarda kaynama süresi ortalamas1 $125.38 \pm 68.09$ gün ve 21 yaş ve üstündeki hastalarda $124.35 \pm 83.29$ gündür. Erkek hastalarda kaynama süresi ortalamas1 $140.32 \pm 87.69$ gün ve kadınlarda $108.83 \pm 55.90$ gündür. Çalışmaya katılan hastalarda lokalizasyon bölgesi alt ekstremite olanlarda kaynama süresi ortalamas1 $128.52 \pm 82.48$ gün ve üst ekstremite olanlarda $118.67 \pm 61.04$ gündür (Tablo 3).

Tümörün kemikteki yerleşim yerinin kaynama süresine etki ettiğini gözlemlendi. Sentetik kemik grefti kullandığımız diafiz tutulumlu dört hastada ortalama kaynama süresi $182.5 \pm 35.9$ gün kansellöz greft kullanılan grupta da $147 \pm 25.4$ gün olarak tespit edildi.

Çalışma sonuçlarına göre sentetik greft kullanılan hastalar ile kansellöz greft kullanılan hastalar arasında kaynama süresi açısından istatistiksel olarak anlamlı fark bulunmaktadır $(U=160,500 \mathrm{p}<0.05)$. Sentetik greft kullanilan hastalarda ortalama kaynama süresi sıra ortalamas1 31.02, kansellöz greft kullanılanlarda 19.67'dir. Buna göre kansellöz greft kullanılan hastalarda kaynama süresi daha düşüktür (Tablo 4)

Çalışmaya katılan sentetik greft kullanılan hastalardan 20 yaş ve altında olanlarda kaynama süresi ortalamas1 $163.33 \pm 79.72,21$ yaş ve üstünde olanlarda $133.91 \pm 54.50$ saptanmış olup, erkeklerde $192.50 \pm 69.46$, kadınlarda $126.20 \pm 58.47$, lokalizasyon bölgesi alt ekstremite olanlarda $155.54 \pm 72.69$ ve üst ekstremite olanlarda $141.10 \pm 66.66$ 'dır. Çalışmaya katılan kansellöz greft kullanılan hastalardan 20 yaş ve altında 
olanlarda kaynama süresi ortalamas1 $92.86 \pm 32.72,21$ yaş ve üstünde olanlarda $115.58 \pm 104.88$, erkeklerde $115.76 \pm 86.15$, kadınlarda $79.89 \pm 38.63$, lokalizasyon bölgesi alt ekstremite olanlarda $109.00 \pm 85.53$ ve üst ekstremite olanlarda $90.63 \pm 41.46$ ' dır (Tablo 5).

Araştırma sonuçlarına göre sentetik greft kullanılan, 20 yaş ve altında olan hastalar ile 21 yaş ve üstünde olan hastalar arasında kaynama süresi açısından istatistiksel olarak anlamlı fark bulunmamaktadır (U=52,000 p>0.05) (Tablo 6).

Araştırma sonuçlarına göre kansellöz greft kullanılan, 20 yaş ve altında olan hastalar ile 21 yaş ve üstünde olan hastalar arasında kaynama süresi açısından istatistiksel olarak anlamlı fark bulunmamaktadır $(\mathrm{U}=77,500$ p>0.05) (Tablo 7).

Araştırma sonuçlarına göre sentetik greft kullanılan, erkek hastalar ile kadın hastalar arasında kaynama süresi açısından istatistiksel olarak anlamlı fark bulunmamaktadır $(\mathrm{U}=50,500 \mathrm{p}>0.05)$.

Araştırma sonuçlarına göre sentetik greft kullanılan, lokalizasyon bölgesi farklı hastalar arasında kaynama süresi açısından istatistiksel olarak anlamlı fark bulunmamaktadır ( $\mathrm{U}=60,500 \mathrm{p}>0.05$ ).

Araştırma sonuçlarına göre kansellöz greft kullanılan, lokalizasyon bölgesi farklı hastalar arasında kaynama süresi açısından istatistiksel olarak anlamlı fark bulunmamaktadır $(\mathrm{U}=71,000 \mathrm{p}>0.05)$.

Tablo 3: Kaynama süresinin değişkenlere göre dağılımı

\begin{tabular}{|c|c|c|c|c|c|c|}
\hline & \multicolumn{5}{|c|}{ Kaynama Süresi } \\
\hline & & Sayı & $\begin{array}{l}\text { Ortalama } \\
\text { (gün) }\end{array}$ & Minimum & Maksimum & ss \\
\hline \multirow{2}{*}{$\begin{array}{l}\text { Kullanılan } \\
\text { Greft }\end{array}$} & Sentetik & 23 & 149,26 & 42 & 319 & 68,95 \\
\hline & Kansellöz & 26 & 103,35 & 34 & 422 & 74,37 \\
\hline \multirow[t]{2}{*}{ Yaş Grubu } & 20 yaş ve altı & 26 & 125,38 & 34 & 319 & 68,09 \\
\hline & 21 yaş ve üstü & 23 & 124,35 & 44 & 422 & 83,29 \\
\hline \multirow[t]{2}{*}{ Cinsiyet } & Erkek & 25 & 140,32 & 34 & 422 & 87,69 \\
\hline & Kadın & 24 & 108,83 & 42 & 209 & 55,90 \\
\hline \multirow{2}{*}{$\begin{array}{l}\text { Lokalizasyon } \\
\text { Bölgesi }\end{array}$} & Alt Ekstremite & 31 & 128,52 & 42 & 422 & 82,48 \\
\hline & Üst Ekstremite & 18 & 118,67 & 34 & 230 & 61,04 \\
\hline
\end{tabular}

Tablo 4: Kaynama sürelerinin greft cinsine göre dağılımı

\begin{tabular}{|l|l|l|l|l|l|l|}
\hline & Kullanılan Greft & n & Sira Ort. & Sira Toplamı & U & p \\
\hline \multirow{3}{*}{ Kaynama Süresi } & Sentetik & 23 & 31,02 & 713,50 & 160,5 & 0,006* $^{*}$ \\
\cline { 2 - 6 } & Kansellöz & 26 & 19,67 & 511,50 & & \\
\cline { 2 - 5 } & Total & 49 & & & & \\
\hline
\end{tabular}

*p<0.05 (Mann Whitney U testi)

Tablo 5: Kaynama sürelerinin sentetik ve kansellöz kemik greftinde değişkenlere göre dağılımı

\begin{tabular}{|c|c|c|c|c|c|c|c|}
\hline & \multicolumn{5}{|c|}{ Kaynama Süresi } \\
\hline & & & $\mathbf{n}$ & Ortalama & Minimum & Maksimum & Ss \\
\hline \multirow{6}{*}{ Sentetik } & \multirow{2}{*}{ Yaş Grubu } & 20 yaş ve altı & 12 & 163,33 & 42 & 319 & 79,72 \\
\hline & & 21 yaş ve üstü & 11 & 133,91 & 44 & 209 & 54,50 \\
\hline & \multirow{2}{*}{ Cinsiyet } & Erkek & 8 & 192,50 & 108 & 319 & 69,46 \\
\hline & & Kadın & 15 & 126,20 & 42 & 209 & 58,47 \\
\hline & \multirow[b]{2}{*}{ Lokalizasyon } & Alt Ekstremite & 13 & 155,54 & 42 & 319 & 72,69 \\
\hline & & $\begin{array}{l}\text { Üst } \\
\text { Ekstremite }\end{array}$ & 10 & 141,10 & 44 & 230 & 66,66 \\
\hline \multirow{6}{*}{ Kansellöz } & \multirow{2}{*}{ Yaş Grubu } & 20 yaş ve alt1 & 14 & 92,86 & 34 & 155 & 32,72 \\
\hline & & 21 yaş ve üstü & 12 & 115,58 & 45 & 422 & 104,88 \\
\hline & \multirow{2}{*}{ Cinsiyet } & Erkek & 17 & 115,76 & 34 & 422 & 86,15 \\
\hline & & Kadın & 9 & 79,89 & 45 & 168 & 38,63 \\
\hline & \multirow[b]{2}{*}{ Lokalizasyon } & Alt Ekstremite & 18 & 109,00 & 45 & 422 & 85,53 \\
\hline & & $\begin{array}{l}\text { Üst } \\
\text { Ekstremite }\end{array}$ & 8 & 90,63 & 34 & 155 & 41,46 \\
\hline
\end{tabular}

Adress for correspondence: Uzm. Dr. Ahmet Fevzi Kekeç, Dörtyol Hatay - Türkiye 
Tablo 6: Sentetik kemik greftinde yaşa göre kaynama süresinin değerlendirilmesi

\begin{tabular}{|l|l|l|l|l|l|l|}
\hline Kullanılan Greft $=$ Sentetik & Yaş Grubu & $\mathbf{n}$ & Sıra Ort. & Sıra Toplamı & U & p \\
\hline \multirow{4}{*}{ Kaynama Süresi } & 20 yaş ve altı & 12 & 13,17 & 158,0 & 52 & 0,38 \\
\cline { 2 - 6 } & 21 yaş ve üstü & 11 & 10,73 & 118,0 & & \\
\cline { 2 - 6 } & Total & 23 & & & & \\
\hline
\end{tabular}

Tablo 7: Kansellöz allogreftte yaşa göre kaynama süresinin değerlendirilmesi

\begin{tabular}{|l|l|l|l|l|l|l|}
\hline \multirow{2}{*}{ Kullanılan Greft = Kansellöz } & Yaş Grubu & $\mathbf{n}$ & $\begin{array}{l}\text { Sira } \\
\text { Ort. }\end{array}$ & $\begin{array}{l}\text { Sıra } \\
\text { Toplamı }\end{array}$ & $\mathbf{U}$ & $\mathbf{p}$ \\
\hline \multirow{3}{*}{ Kaynama Süresi } & 20 yaş ve altı & 14 & 13,96 & 195,50 & 77,500 & 0,738 \\
\cline { 2 - 6 } & 21 yaş ve üstü & 12 & 12,96 & 155,50 & & \\
\cline { 2 - 5 } & Total & 26 & & & & \\
\hline
\end{tabular}

\section{TARTIŞMA}

Benign kemik tümörleri genellikle kavitenin küretaj1, agresif tümörlerde adjuvan uygulanması ve oluşan defektin doldurulması ile tedavi edilir. Günümüzde defekti doldurmak için Polimetilmetakrilat (PMMA), sentetik kemik grefti, allogreft kemik ve otogreft kemik kullanılmaktadır. PMMA kemik stoğunu korumamakta ve sertleşmiş sement kemikle aynı biyomekanik özellikleri paylaşmamaktadır (6). Allogreftlerin bulaşıc1 hastalık, derin enfeksiyon ve nonunion riskleri mevcut olup biyolojik özellikleri hazırlandıktan sonra değişmektedir $(7,8)$. Otogreftlerde donör saha morbiditesi mevcut olup miktarları sınırlıdır (9). Bazı yazarlar defektleri boş bırakmayı önermekte fakat bu da erken kırık ya da kollapsa sebep olabilmektedir (10).

$\mathrm{Bu}$ kisıtlılıklardan kaçınmak için sentetik kemik greftlerinin kullanımı giderek popüler hale gelmiştir. Bunlar bulaşıcı hastalık riskini, donör saha morbiditesini yok etmekte homojen partikül büyüklüğünde işlenmekte, sinırsı miktarda elde edilebilmekte ve erken fonksiyonel rehabilitasyona izin verebilecek yeterli mekanik destek sağlayabilmektedirler.

Bizim çalışmamızda 26 benign kemik tümörlü hastaya sentetik kemik grefti 26 hastaya da kansellöz allogreft kullanılarak ikisi arasındaki kaynama oranları materyalinin tam rezorpsiyonu/greft alanında tam kemik oluşumu post-operatif radyografiler ile değerlendirilmiştir.

Literatürde bizim çalışmamız dışında beta kalsiyum trifosfat sentetik grefti ile kansellöz allogrefti karşılaştıran başka yayın bulunmamaktadır. Yang ve arkadaşlarının yaptığı 50 'şer hastalık karşılaştırmalı bir çalışmada kalsiyum sülfat ve allogreft ile tedavi edilen kemik kaviteleri irdelenmiş ve kaynama süreleri ve komplikasyonlar açısından istatistiksel olarak anlamlı fark tespit edilememiştir.

Kotnis ve arkadaşlarının 2011 yılında yaptıkları çalışmada benign kemik tümörü nedenli ameliyat sonrasi kalsiyum sülfatkalsiyum fosfat sentetik greftlerinin kullanıldığ1 ve birbirini izleyen radyografik değerlendirmeleri yapılmış 11 hastadan oluşan seriden 2'si tam kemikleşme görülmeden nüks etmesi üzerine çalışma dışı bırakılmış, geri kalan 9'unda ise greft materyalinin tam rezorpsiyonu/greft alanında tam kemik oluşumu 5 aydan fazla süren takipten sonra hastaların \% 89'unda (8/9) izlenmiştir. Diğer hastada (1/9) ise operasyondan 14 ay sonra tam kemik gelişimi henüz sağlanamamışken tümör nüks etmiştir. Tam kemikleşme süresi ortalama 5 ay olarak saptanmıştır (11).

Ewaniev ve arkadaşlarının 2007-2012 yılları arasında opere ettikleri 24 benign kemik tümörü olan hasta retrospektif olarak incelenmiş, intralezyonel küretaj sonrası oluşan kemik defektleri "Pro-Dense (Calcium Sulfate-Calcium Phosphate Synthetic Bone Graft Composite)" ile rekonstrukte edilmiştir. Prodense ile tam radyolojik rezorbsiyon ve yeni kemik oluşumu tipik olarak postop 5 . ayda görüldüğü saptanmıştır (12).

Saikia ve arkadaşları beta TCP (beta trikalsiyum fosfat) veya HA (hidroksiapetit) ile rekonstrukte edilen 24 hastayı incelemiş ve ortalama 14. haftada tam yük verme raporlamışlardır. $\mathrm{Bu}$ rekonstrüksiyonların 
hemen hemen $1 / 3$ ünde kemik greftiyle beraber otogreft veya implant da kullanılmıştır. 24 hastanın 20'sinde HA, 4'ünde beta TCP kullanılmış, kaynama süresi ortalama 9 ay (618 ay) olarak saptanmıştır (13).

Siegal ve arkadaşları 18 ay takip ettikleri 51 hastayı beta TCP ve otojen kemik iliği aspiratı kompozitiyle tedavi etmişlerdir. 47 hasta 6 . haftada limitsiz günlük aktivitelere dönebilmiş, hastaların bir grubunda internal fiksasyon, menteşeli ortez ve alçı kullanılmıştır. (14)

Köpek denekler üzerinde yapılan bir çalışmada kullanılan sentetik greft alaşımları sonras1 ortalama ve 13. haftadaki histolojik kesitlerde yaygın kemik oluşumu ve nerdeyse tam rezorpsiyon izlenmiştir. Köpekler üzerinde yapılan başka bir çalışmada ise defektin histolojik olarak tam iyileşmesi 4. ayda olmuştur (15).

Yamamoto ve arkadaşları 75 benign kemik tümörlü hastada oluşan defekti greftlerken hidroksiapatit ve trikalsiyum fosfat içeren komposit greft kullanmışlardır (16). Yazarlar kemik greftini çevreleyen radyolusen zonun ortalama 4.2 ayda kaybolduğunu ve bunun konsolidasyonun bir işareti olduğunu öne sürmüşlerdir.

Çalışmamızda greft kaynama süresi sentetik greft kullanılan hastalarda ortalama $149.26 \pm 68.95$ gün ve kansellöz allogreft kullanılan hastalarda ise $103.35 \pm 74.37$ gündür. Sentetik greft kullanılan hastalar ile kansellöz greft kullanılan hastalar arasında kaynama süresi açısından istatistiksel olarak anlamlı fark bulunmaktadir $(\mathrm{U}=160,500 \mathrm{p}<0.05)$. Buna göre kansellöz greft kullanılan hastalarda kaynama süresi daha kısadır. Allogreftler; poroz yapıları içinde progenitor hücrelerin ve endotelyal hücrelerin tutundugu birçok kimyasal alan içerirler. Aynı zamanda, osteoklastlar tarafindan rezorbe edildiklerinde serbest kalan kemik matriks içinde büyüme faktörleri de içerirler. Allogreft kemikte, osteoindüktif özellik taşıyan az miktarda kemik morfojenik proteini de (BMP) bulunur. Otogen greftlere göre çok düşük olsada osteoindüktif kapasiteleri mevcuttur fakat standart sentetik kemik greftlerinde osteoindüktif kapasite yoktur.

Çalışmamızda kaynama süresini etkileyebilecek ek faktörler açısından; yaş, cinsiyet, lokalizasyon gibi faktörlerde değerlendirilmiş fakat istatistiksel anlamlılık saptanmamıştır. Her ne kadar istatistiksel olarak anlamlı çıkmasa da sonuçlara ve gözlemlerimize göre kemiğin diafiz bölgesindeki tümörlerde kaynama süreleri daha uzun olmaktadır. Bu da greftin konulacağ 1 alanın (epifiz, metafiz, diafiz) vaskülaritesinin kaynama süresi üzerine önemli etkisi olduğunu desteklemektedir.

Çalışmamızda küretaj ve greftleme ile tedavi edilen benign kemik tümörleri kitle boyutlarına göre sınıflandırılmamış ve bu anlamda istatistiksel veri elde edilmemiştir. $\mathrm{Bu}$ çalışmada periferik greft rezorbsiyonunun ve yeni kemik oluşumunun başlama süresi baz alınmıştır çünkü defektin tamamen konak kemikle konsolide olması kitle boyutlarıyla doğru orantılıdır.

Sonuç olarak kemik greftinin endike olduğu vakalarda otolog kemik grefti hala altın standart olmakla beraber kullanımı kisıtlayan birçok dezavantajı vardır (donör saha morbiditesi ve sinırlı greft alınabilmesi). Allogreftlerde bu tip sinırlamalar yoktur ama hastalık geçis riski, bir donöre veya kadavraya ihtiyaç duyulması, sterilizasyon ve saklama koşulları ve maliyet sorunları mevcuttur. Sentetik kemik greftleri tam biyo-uyumlu olmaları, kaynak sınırı olmaması, saklama koşullarının ve sterilizasyon işlemlerinin kolaylığ1 kaynama sürelerinin allogreftlere yakın olmas1, büyüme faktörleri, ilaçlar; antibiyotik, antikanser vb. ilaçlar için taşıyıcı olarak kullanılabilmesi gibi avantajlarından dolayı gelecekte daha da ilgi odağı olacaktır.

\section{Çıkar Çatışması: Yok}

\section{REFERANSLAR}

1. Hirn M, De Silva U, SidharthanS, Grimer RJ, Abudu A, Tillman RM, et al. Bone defects following curettage do not necessarily need augmentation. Acta Orthopaedica. 2009; 80(1) $4-7$.

2. Yip KMH, Leung PC, Kumta SM. Giant cell tumors of bone. Clin Orthop. 1996; 323: 60 64.

3. Glancy GL, Brugioni DJ, Eilert RE, Chang FM. Autograft versus allograft for benign lesions in children. Clin Orthop. 1991; 262: $28-33$.

4. Schlickewie W, Schlickewie C. The use of bone substitutes in the treatment of bone defects - the clinical view and history. Macromol Symp. 2007;253(1): 10 - 23 
5. Lerner T, Bullmann V, Schulte TL, Schneider M, Liljenqvist U. A level-1 pilot study to evaluate of ultraporous betatricalcium phosphate as a graft extender in the posterior correction of adolescent idiopathic scoliosis. Eur Spine J. 2009; $18(2) 170-179$.

6. Campanacci M, Capanna R, Fabbri N, Bettelli G. Curettage of giant cell tumor of bone. reconstruction with subchondral grafts and cement. Chir Organi Mov. 1990; 75(1 suppl):212-213.

7. Mankin HJ, Gebhardt MC, Jennings LC, Springfield DS, Tomford WW. Long-term results of allograft replacement in the management of bone tumors. Clin Orthop Relat Res. 1996; (324):86-97.

8. Temple HT, Malinin TI. Microparticulate cortical allograft: an alternative to autograft in the treatment of osseous defects. Open Orthop J. 2008; 2:91-96.

9. Turcotte RE, Wunder JS, Isler MH, et al. Giant cell tumor of long bone: a Canadian sarcoma group study. Clin Orthop Relat Res. 2002; (397):248-258.

10. Prosser GH, Baloch KG, Tillman RM, Carter SR, Grimer RJ. Does curettage without adjuvant therapy provide low recurrence rates in giant-cell tumors of bone? Clin Orthop Relat Res. 2005; (435):211-218.

11. Kotnis NA, Parasu N, Finlay K, Jurriaans E, Ghert M.Chronology of the radiographic appearances of the calcium sulphate-calcium phosphate synthetic bone graft composite following resection of bone tumours-a preliminary study of the normal post-operative appearances. Skeletal Radiol. 2011 May;40(5):563-70

12. Evaniew N, Tan V, Parasu N, JurriaansE. Finlay K,Deheshi B, Ghert M. Use of a Calcium Sulfate-Calcium Phosphate Synthetic Bone Graft Composite in the Surgical Management of Primary Bone Tumors: Orthopaedics 2013 Feb;36(2):e216-22

13. Saikia KC, Bhattacharya TD, Bhuyan SK, Talukdar DJ, Saikia SP, Jitesh P. Calcium phosphate ceramics as bone graft substitutes in filling bone tumor defects. Indian $\mathrm{J}$ Orthop. 2008; 42(2):169-172.

14. Saikia KC, Bhattacharya TD, Bhuyan SK, Talukdar DJ, Saikia SP, Jitesh P. Calcium phosphate ceramics as bone graft substitutes in filling bone tumor defects. Indian $\mathbf{J}$ Orthop. 2008; 42(2):169-172.

15. Podaropoulos L, Veis A, Papadimitriou S, Alexandridis C, Kalyvas D. Bone regeneration using b-tricalcium phosphate in a calcium sulfate matrix. J Oral Implantol. 2009;35(1):28-36

16. Yamamoto $T$, Onga $T$, Mizuno $K$. Use of hydroxyapatite to fill cavities after excision of benign bone tumours. Clinical results. J Bone Jt Surg. 2000;82-B:1117-20. 